\title{
A Dominant Voice amidst Not Enough People: Analysing the Legitimacy of Mexico's REDD+ Readiness Process
}

\author{
Jovanka Špirić ${ }^{1, *}$, Esteve Corbera ${ }^{1}$, Victoria Reyes-García ${ }^{1,2}$ and Luciana Porter-Bolland ${ }^{3}$ \\ 1 Institute of Environmental Science and Technology, Universitat Autònoma de Barcelona, \\ 08193 Bellaterra, Spain; esteve.corbera@uab.cat (E.C.); victoria.reyes@uab.cat (V.R.-G.) \\ 2 Institució Catalana de Recerca i Estudis Avançats (ICREA), Pg. Lluís Companys 23, 08010 Barcelona, Spain \\ 3 Instituto de Ecología, A. C., Red de Ecología Funcional, Carretera Antigua a Coatepec 351, El Haya, \\ 91070 Xalapa, Mexico; luciana.porter@inecol.mx \\ * Correspondence: vankajo@yahoo.com; Tel.: +381-638275058
}

Academic Editors: Damian C. Adams and Timothy A. Martin

Received: 28 September 2016; Accepted: 30 November 2016; Published: 10 December 2016

\begin{abstract}
In the development of national governance systems for Reducing Emissions from Deforestation and forest Degradation (REDD+), countries struggle with ensuring that decision-making processes include a variety of actors (i.e., input legitimacy) and represent their diverse views in REDD+ policy documents (i.e., output legitimacy). We examine these two dimensions of legitimacy using Mexico's REDD+ readiness process during a four-year period (2011-2014) as a case study. To identify REDD+ actors and how they participate in decision-making we used a stakeholder analysis; to assess actors' views and the extent to which these views are included in the country's official REDD+ documents we conducted a discourse analysis. We found low level of input legitimacy in so far as that the federal government environment agencies concentrate most decision-making power and key land-use sectors and local people's representatives are absent in decision-making forums. We also observed that the REDD+ discourse held by government agencies and both multilateral and international conservation organisations is dominant in policy documents, while the other two identified discourses, predominantly supported by national and civil society organisations and the academia, are partly, or not at all, reflected in such documents. We argue that Mexico's REDD+ readiness process should become more inclusive, decentralised, and better coordinated to allow for the deliberation and institutionalisation of different actors' ideas in REDD+ design. Our analysis and recommendations are relevant to other countries in the global South embarking on REDD+ design and implementation.
\end{abstract}

Keywords: discourses; legitimacy; Mexico; REDD+; stakeholder analysis

\section{Introduction}

Reducing Emissions from Deforestation and forest Degradation, plus the conservation, sustainable management of forests, and enhancement of forest carbon stocks (REDD+) is an emergent global forest governance regime under the auspices of the United Nations Framework Convention on Climate Change (UNFCCC). REDD+ is intended to align the views of a variety of actors who are active across different social and political jurisdictions on how to frame and address the problem of deforestation and forest degradation in developing countries [1-6]. During the last decade, REDD+ has become increasingly relevant in the environmental and land-use policy agendas of many developing countries. To date, around 50 countries in the global South are involved in the so-called readiness phase-the first of three phases in REDD+ design and implementation [7,8]. These countries have been building institutional capacity and developing national strategies, which contain guidelines for the design of REDD+ policies 
and activities that will be operationalised during the implementation phase, while any potential resulting emission reductions will be accounted for and rewarded in the performance phase $[9,10]$.

The "Warsaw Framework for REDD+" provides the rules and guidance that developing countries should follow to ensure an effective and sustained REDD+ implementation [11], and several studies have investigated the legitimacy of such international REDD+ governance negotiations [12-14]. However, as REDD+ will ultimately be implemented at the national level [15] and jurisdictional or sub-national approaches to REDD+ have been officially accepted as interim measures towards a full national approach [11], the legitimacy of REDD+ national governance (i.e., how non-state actors are involved in REDD+ decision-making and to which extent their ideas and views permeate the design and implementation of REDD+ policies and activities [16,17]) will be determined by host countries' governance processes, which deserve detailed scrutiny (e.g., [18] this special issue).

The legitimacy of environmental governance encompasses the legitimacy of the process as well as its outcomes, the so-called input and output legitimacy $[19,20]$. Input legitimacy concerns the extent to which actors are recognised, included, and represented in negotiations. It also refers to whether negotiations are transparent and all participants are accountable to one another and engage in discussions and decision-making on a voluntary and equal basis [20-22]. Output legitimacy refers to the level of actors' acceptance of adopted decisions and the outcomes of their implementation [20,23-25]. In the context of REDD+ readiness, input legitimacy concerns the design of national REDD+ decision-making processes through which governments should share their power in addressing deforestation and forest degradation with other actors. In turn, output legitimacy concerns the extent to which the general idea of REDD+ is either contested or accepted by these actors and how their different views on REDD+ key issues become acknowledged in government approved national REDD+ documents.

Despite the growing importance of REDD+ social safeguards, which call for a full and effective participation of all relevant stakeholders [26], most REDD+ pursuing countries still face the challenge of designing legitimate decision-making processes [27-37]. Using Mexico as a case study, this article contributes to these debates by investigating the legitimacy of the country's REDD+ readiness process over a four-year period. To evaluate the level of input legitimacy, we identify the key REDD+ actors and analyse their relevance, influence, and interest in the readiness process, as well as their perceptions on the legitimacy of national REDD+ discussions. To evaluate the level of output legitimacy, we identify the principal discourses that have emerged around REDD+ and calculate the degree to which the ideas embedded in actors' discourses are reflected in the two most advanced REDD+ policy documents at the time of this research: Mexico's Emission Reductions Initiative Idea Note (ER-PIN, August 2013) and the fifth draft of the National REDD+ Strategy (ENAREDD+, November 2014; with ENAREDD+ representing its Spanish acronym—similar naming/referencing conventions will appear throughout this document for the names of other forums and organisations that were originally in Spanish).

\section{Case Study and Methods}

\subsection{REDD+ Governance in Mexico}

Mexico showed an early interest in REDD+ and was the first country to submit the Readiness Plan Information Note (R-PIN) in 2008 and the Readiness Preparation Proposal (R-PP) in 2010 to the Forest Carbon Partnership Facility (FCPF) — the World Bank's multilateral readiness platform that provides technical and financial support to REDD+ developing countries [38-40]. Furthermore, aiming to explore and test different REDD+ institutional and financial arrangements, Mexico's government has been implementing REDD+ early actions since 2010 through the existing National Forest Commission's (CONAFOR) programmes and the newly launched "special programmes" [41]. Several local REDD+ pilot projects promoted by non-governmental organisations (NGOs) have also been implemented [42-44].

In 2009, the Mexican federal government created a cross-sectorial body to coordinate government sectors relevant to REDD+, known as the Working Group for REDD+ (GT-REDD+) [45]. A year later, in 2010, the government promoted a multi-stakeholder consultative forum, known as the national 
Technical Advisory Committee for REDD+ (CTC-REDD+, hereafter CTC) to involve non-state actors in the REDD+ readiness phase. Several sub-national CTCs were also established in 2011 in states selected for early REDD+ implementation (i.e., Oaxaca, Chiapas, Yucatán, Campeche, Quintana Roo, and Jalisco) [46]. In addition, the government reformed the General Law on Ecological Equilibrium and Environmental Protection (LGEEPA) and the General Law on Sustainable Forest Development (LGDFS) to facilitate REDD+ design and implementation in the same year [47,48]. In 2013, another national level consultative multi-stakeholder forum, the Working Group on ENAREDD+ (GT-ENAREDD+), was established under the National Forest Council (CONAF) [49].

The REDD+ readiness process in Mexico had a first intermediate product in 2010: Mexico's REDD+ Vision. This document identified sustainable rural development as the key governing principle for REDD+ implementation and defined five strategic lines for the development of the national REDD+ strategy (ENAREDD+): (a) institutional arrangements and public policies; (b) financing mechanisms; (c) monitoring, reporting, and verification (MRV) systems—in place to measure the country's performance in terms of forest related emissions and removals [50]; (d) communication, participation, and transparency; and (e) environmental and social safeguards [51]. From 2011 to 2014, six ENAREDD+ drafts were produced providing further details on specific activities to be implemented within each strategic line [45,51-54]. In 2013, CONAFOR elaborated Mexico's Emission Reductions Initiative Idea Note (ER-PIN), a document required by the FCPF Carbon Fund, which expands on key REDD+ design issues such as benefit-sharing, scope of activities (only conservation or also productive activities), and expected co-benefits (non-carbon benefits, including social, environmental, and governance benefits [11]) [55,56]. As Figure 1 suggests, although CONAFOR endorses the official national REDD+ documents, they should theoretically include the views and ideas of the actors involved in the CTC and GT-ENAREDD+ forums.

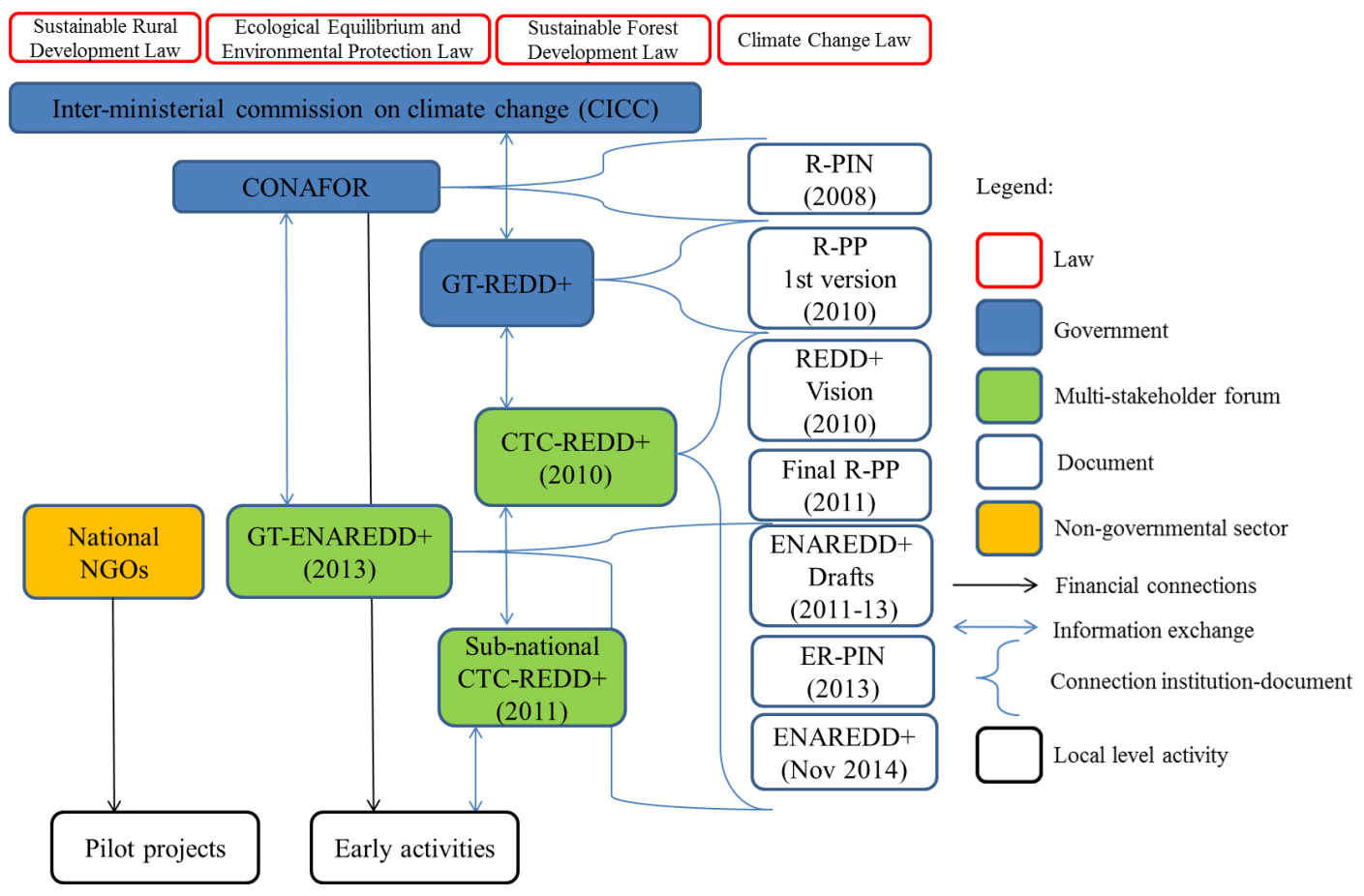

Figure 1. Main laws, documents, and activities in Mexico's REDD+ readiness governance system and their authoring and/or implementing actors and consultative forums. Source: own elaboration. REDD+, Reducing Emissions from Deforestation and forest Degradation; ENAREDD+, Mexico's national REDD+ strategy in Spanish; CONAFOR, National Forest Commission; R-PIN, Readiness Plan Information Note; R-PP, Readiness Preparation Proposal; ER-PIN, Mexico's Emission Reductions Initiative Idea Note; CTC-REDD+, Technical Advisory Committee for REDD+; GT-REDD+, Working Group for REDD+; GT-ENAREDD+, Working Group on ENAREDD+; NGOs, non-governmental organisations. 


\subsection{Data Collection}

Data collected for this article includes secondary and primary sources. Secondary sources include information collected from Mexico's REDD+ actors' publications and reports, key official documents, open letters and other media communications, and minutes from the above-described multi-stakeholders REDD+ forums, both in English and in Spanish, and published up to December 2014. These documents helped us in understanding the evolution of REDD+ in Mexico because they included written statements that captured actors' general views on REDD+ design and implementation. We acknowledge that actors can change their position in regards to REDD+ issues, but for the purpose of the analysis presented here, we only consider the predominant position of the actor for a given theme over the research period. The first author also collected primary data on participant actors' discussions and decision-making procedures during her participation in REDD+ related forums and events. These events included: The Commission for State Development Planning-Quintana Roo, 17 and 28 June 2011; U'yool'che's REDD+ workshop with local communities, 9 and 10 July 2011; The Nature Conservancy's deforestation workshop, 10 and 11 July 2011; U'yool'che's workshop on the community's protected area, 12 July 2011; Universidad Nacional Autónoma de México's roundtable on the Law on Ecological Equilibrium and Environmental Protection, 20 July 2011; Consejo Mexicano de Silvicultura Sostenible's REDD+ workshop, 9 August 2011; Aliance Sian Ka'an-Calakmul's REDD+ workshop, 16 August 2011; CTC-Quintana Roo session, 14 October 2013; El Consejo Regional Indígena y Popular de Xpujil's meeting, 29 November 2013; and the state of Campeche environmental agency's working meeting on REDD+ with CONAFOR, 14 February 2014.

The information from the documents and meetings helped us evaluate the actors' interest in and power to influence the REDD+ readiness process, and strengthened the analysis of their views on REDD+ design and implementation. They helped in developing a list of potential interviewees with a stake in Mexico's forestry and land-use sectors as well as of actors that could be affected by future REDD+ implementation in the country. This non-comprehensive list of interviewees included representatives from all sectors relevant to REDD+ design and implementation at federal level. At the local level, it included actors from two early action regions of the Yucatán peninsula and the state of Chiapas, which were prioritised to investigate the legitimacy of the readiness phase at sub-national level. Additional REDD+ actors were identified through snowball sampling in initial interviews $[57,58]$.

The first author conducted 41 face-to-face semi-structured interviews during two periods of fieldwork (June-August 2011 and September 2013-February 2014). Specifically, 16 interviewees belonged to national and three to international NGOs, ten to federal and three to state governments, six to academic institutions, and three involved local representatives from the communities of Felipe Carrillo Puerto in Quintana Roo, and La Mancolona and Xmaben in Campeche. These communities were chosen because they are located in REDD+ development priority regions and were part of a larger research project in which the authors were involved. Local communities' views about REDD+ were also captured through the secondary sources highlighted above, such as newspapers and official letters, as well as in REDD+ forums and events. The interview guide included three sections addressing (i) actors' roles in REDD+ readiness and their external reasons and internal motivations to participate (or not) in the process; (ii) actors' perceptions of the REDD+ decision-making process; and (iii) actors' general opinions on REDD+ and its design and operational issues. The interviews lasted about one and a half hours, were conducted in Spanish, recorded (with consent), and subsequently transcribed for analysis.

\subsection{Data Analysis}

\subsubsection{Qualitative Content Analysis}

We used a qualitative content analysis software programme (MaxQDA) to assign codes related to eight key issues in REDD+ design and implementation to paragraphs or sentences in the interview and event transcripts, as well as in the analysed publications and reports. The eight key issues selected 
were deforestation drivers, REDD+ definitions, implementation scale, scope of activities, carbon rights, land tenure, participation, and decision-making procedures. The segments containing the same codes were grouped in documents and translated into English. The results of an interpretative analysis of these documents informed the stakeholder and the discourse analyses.

\subsubsection{Stakeholder Analysis}

We used stakeholder analysis to evaluate the input legitimacy of Mexico's REDD+ readiness phase. Specifically, we used the interview transcripts and the published documents to evaluate an actor's relevance, power to influence, and interest in REDD+. For these three characteristics, we used a three-grade system (high, moderate, and low). Relevance was determined based on the potential impact that a given actor's activities might have on REDD+ effectiveness (i.e., in reducing land-use emissions and increasing removals) [59]. Influence was determined based on the extent to which an actor was likely to persuade or coerce other actors into following certain courses of action in REDD+ design and implementation [60]. Since the level of persuasion and coercion was not specifically assessed in the interviews, we used information about the actor's REDD+ financial resources and position in formal social hierarchies, specifically in REDD+ decision-making bodies to assess the actor's influence [61]. Finally, interest was measured based on (i) the actor's role as financial investor in REDD+; (ii) the frequency of actor's participation in both governmental and alternative REDD+ readiness events; and, (iii) the amount of documents that contribute to REDD+ discussions produced by the actor $[60,62]$ (Table 1).

Table 1. Description of actor's relevance, influence, and interest in REDD+. Source: own elaboration.

\begin{tabular}{|c|c|c|c|}
\hline Attributes Level & High & Moderate & Low \\
\hline Relevance & $\begin{array}{l}\text { Actors who design or } \\
\text { implement public policies and } \\
\text { activities that directly } \\
\text { contribute to land-use change, } \\
\text { either increasing or decreasing } \\
\text { carbon stocks }\end{array}$ & $\begin{array}{l}\text { Actors who provide } \\
\text { financial resources and/or } \\
\text { information for the } \\
\text { development of specific } \\
\text { land-use change activities } \\
\text { that either increase or } \\
\text { decrease carbon stocks }\end{array}$ & $\begin{array}{l}\text { Actors whose activities } \\
\text { do not have an impact } \\
\text { (or whose impact would } \\
\text { be hard to prove) on } \\
\text { land-use change }\end{array}$ \\
\hline Influence & $\begin{array}{l}\text { Actors who are primary } \\
\text { recipients of relevant financial } \\
\text { resources for REDD+ or who } \\
\text { can directly influence policies } \\
\text { given their position in formal } \\
\text { social hierarchies }\end{array}$ & $\begin{array}{l}\text { Actors receiving REDD+ } \\
\text { financial resources from } \\
\text { government, thus } \\
\text { steering REDD+ design } \\
\text { in ways that meet } \\
\text { their expectations }\end{array}$ & $\begin{array}{l}\text { Actors who do not } \\
\text { hold significant financial } \\
\text { REDD+ resources and } \\
\text { who are not present } \\
\text { in formal REDD+ } \\
\text { decision-making forums }\end{array}$ \\
\hline Interest & $\begin{array}{l}\text { Actors who financially invest } \\
\text { in REDD+ and/or regularly } \\
\text { participate in either the } \\
\text { governmental or alternative } \\
\text { REDD+ forums, contributing } \\
\text { to discussions in oral and/or } \\
\text { written forms }\end{array}$ & $\begin{array}{l}\text { Actors with all } \\
\text { preconditions to } \\
\text { participate (e.g., financial } \\
\text { resources, invited to } \\
\text { meetings) but who only } \\
\text { intermittently participate } \\
\text { in the governmental } \\
\text { or alternative REDD+ oral } \\
\text { or written discussions }\end{array}$ & $\begin{array}{l}\text { Actors who were } \\
\text { formally invited to } \\
\text { participate in either the } \\
\text { governmental } \\
\text { or alternative REDD+ } \\
\text { forums, but neither } \\
\text { participated nor } \\
\text { communicated their } \\
\text { views on REDD+ }\end{array}$ \\
\hline
\end{tabular}

\subsubsection{Discourse Analysis}

Stakeholders articulate their views of reality through discourses [63], which are defined as the shared ways of understanding and perceiving the world [64,65]. Environmental discourses frame how we conceive environmental problems (e.g., deforestation) and related policies (e.g., REDD+) [66]. Given that by constructing and reproducing REDD+ discourses, actors legitimise or delegitimise REDD+ governance [65-71], we used discourse analysis to assess the output legitimacy of REDD+ governance in Mexico's readiness phase as well as the actors' perceptions on the legitimacy of REDD+ readiness discussions. The analytical framework we developed to identify and examine REDD+ discourses in 
Mexico combines three elements suggested by Dryzek [65]: key storylines, main discursive agents, and key metaphors.

Key storylines are a collection of actors' stances on ten central REDD+ dimensions including (i) three REDD+ conceptual dimensions (i.e., REDD+ goals and its role within climate change governance; drivers of deforestation; and the role of local communities in deforestation) and (ii) seven REDD+ strategic dimensions (i.e., REDD+ implementation scale; benefit-sharing strategy; scope of activities; co-benefits; safeguards; impact on land and tenure; and carbon rights). The discursive agents represent the actors who, through the storylines, are characterised as the archetypes of "heroes" and "culprits" (i.e., those who positively or negatively contribute to forest conservation and REDD+ effectiveness), or as "winners" and "losers" (i.e., those who will benefit the most or become worse off from REDD+). Finally, key metaphors are two or three keywords or phrases used in storylines to symbolise the discourse (e.g., 'win-win-win').

We used the results of qualitative content analysis to identify ten key storylines that each REDD+ actor in Mexico put forward for each conceptual and strategic dimension highlighted above. Specifically, we grouped into discourse coalitions the actors who share the usage of a particular set of storylines [64]. We further explored overlaps and conflicts between different discourse coalitions by identifying whether they promote the same or opposed storylines. Hajer [72] suggests that a discourse becomes hegemonic if policy actors are required to use its vocabulary and concepts to appear credible (discourse structuration), and if such discourse fully permeates into policy decisions and institutional arrangements and practices (discourse institutionalisation). In reality, discourse structuration and institutionalisation occur only to a certain degree, resulting in a weaker form of hegemony or discursive domination [72].

As we analysed discourses about REDD+, and all policy actors used the REDD+ terminology in their storylines, we evaluated the degree of discourse structuration by calculating the proportion to which the storylines on conceptual REDD+ dimensions were represented, explicitly or implicitly, in either of the two most advanced REDD+ policy documents by the time we concluded data collection (i.e., the fifth ENAREDD+ draft and the ER-PIN). We evaluated discourse institutionalisation by calculating the extent to which the storylines on strategic REDD+ dimensions were represented, explicitly or implicitly, in any of the named documents. Therefore, if a discourse had all its storylines on REDD+ conceptual issues (in our case three) and half or more (in our case between four and seven) of those focused on strategic dimensions represented in the documents, we considered that discourse as 'dominant'. If a discourse had less than three of the storylines related to REDD+ conceptual issues and less than four of the storylines concerned with strategic REDD+ issues represented in the documents, we considered it as 'marginalised' (see Table 2).

Table 2. Rules to determine the degree of discourse influence according to the representation of storylines discussing REDD+ conceptual and strategic dimensions as they appear in selected policy documents. The number of storylines is in brackets. Source: own elaboration.

\begin{tabular}{ccc}
\hline Conceptual Dimensions & All Storylines (3) & Less Than Three Storylines (2 or less) \\
Strategic Dimensions & & Marginalised \\
\hline Four or more storylines (4-7) & Dominant & Marginalised \\
Less than four storylines (0-3) & Marginalised \\
\hline
\end{tabular}

Finally, to assess the overall legitimacy of REDD+ readiness in Mexico, we plotted the actors' perceptions of input and output legitimacy using a two-grade system (granted and not granted) (Table 3). We used the actors' perceptions on the legitimacy of the REDD+ decision-making process organised through the CTC to represent the level of input legitimacy. In the case of output legitimacy, and since the actors' perceptions on the content of REDD+ documents were not specifically assessed in 
the interviews, we used the degree of discourse influence as an indicator of the likely actors' levels of acceptance and endorsement of REDD+ policy documents.

Table 3. Rules to evaluate the overall legitimacy of REDD+ governance in Mexico. Source: own elaboration.

\begin{tabular}{|c|c|c|}
\hline $\begin{array}{l}\text { Input Legitimacy } \\
\text { Output Legitimacy }\end{array}$ & Granted & Not Granted \\
\hline Granted & $\begin{array}{l}\text { Actors who perceive the CTC } \\
\text { as a legitimate forum and share } \\
\text { a 'dominant' discourse }\end{array}$ & $\begin{array}{l}\text { Actors who perceive the CTC as } \\
\text { an illegitimate forum and share } \\
\text { a 'dominant' discourse }\end{array}$ \\
\hline Not granted & $\begin{array}{l}\text { Actors who perceive the CTC } \\
\text { as a legitimate forum and share } \\
\text { a 'marginalised' discourse }\end{array}$ & $\begin{array}{l}\text { Actors who perceive the CTC as } \\
\text { an illegitimate forum and share } \\
\text { a 'marginalised' discourse }\end{array}$ \\
\hline
\end{tabular}

\section{Results}

\subsection{REDD+ Stakeholders}

The identified actors were categorised into eight stakeholder groups based on their relevance and ability to influence REDD+ readiness. Out of the nine theoretically possible stakeholder groups, there were none with low relevance but high ability to influence REDD+ design. We named the identified groups as: top holders, followers, frontliners, money patrons, intermediaries, on the ground, information providers, and observers, deriving labels from the most common role or position that group members have in REDD+ readiness (Figure 2).

Top holders include federal environmental agencies that are very relevant for REDD+ effectiveness as they design environmental and forestry policy and legal frameworks that should be conducive to forest conservation and reduce rates of land-use change. Among the top holders, the Environment Ministry (SEMARNAT) holds the highest position in the formal social hierarchy, which makes it very influential in REDD+. SEMARNAT's high level of influence and interest in REDD+ emanates from the joint participation in readiness discussions and activities of its decentralised federal agencies for protected areas (CONANP), environmental protection (PROFEPA), and ecology and climate change (INECC), in addition to a permanent interdepartmental commission for knowledge and use of biodiversity (CONABIO). Despite being one of SEMARNAT's decentralised agencies, CONAFOR is the most influential REDD+ actor in Mexico, as it is the national focal point under the UNFCCC negotiations and controls the largest sum of REDD+ readiness financial resources. CONAFOR is also the CTC convenor and the lead author of the policy documents analysed.

Followers include the federal ministry of agriculture (SAGARPA), which is responsible for the design and implementation of agricultural public policies, a major driver of deforestation. Despite SAGARPA's high position in the formal hierarchy, this agency does not manage REDD+ funds and has had a secondary role in the readiness phase. SAGARPA's frequency of participation in CTC meetings has declined over the years, currently showing a moderate level of interest in REDD+. Followers also include the state environmental agencies in early action regions (e.g., SMAAS-Campeche; SEMA-Quintana Roo; SEMAHN-Chiapas), who have a moderate influence because the sub-national authorities manage only a limited share of the federal budget and are financially subordinated to the central government [73]. These sub-national agencies, however, have high interest in REDD+, being leaders of state CTCs and lead authors of sub-national REDD+ strategies. 


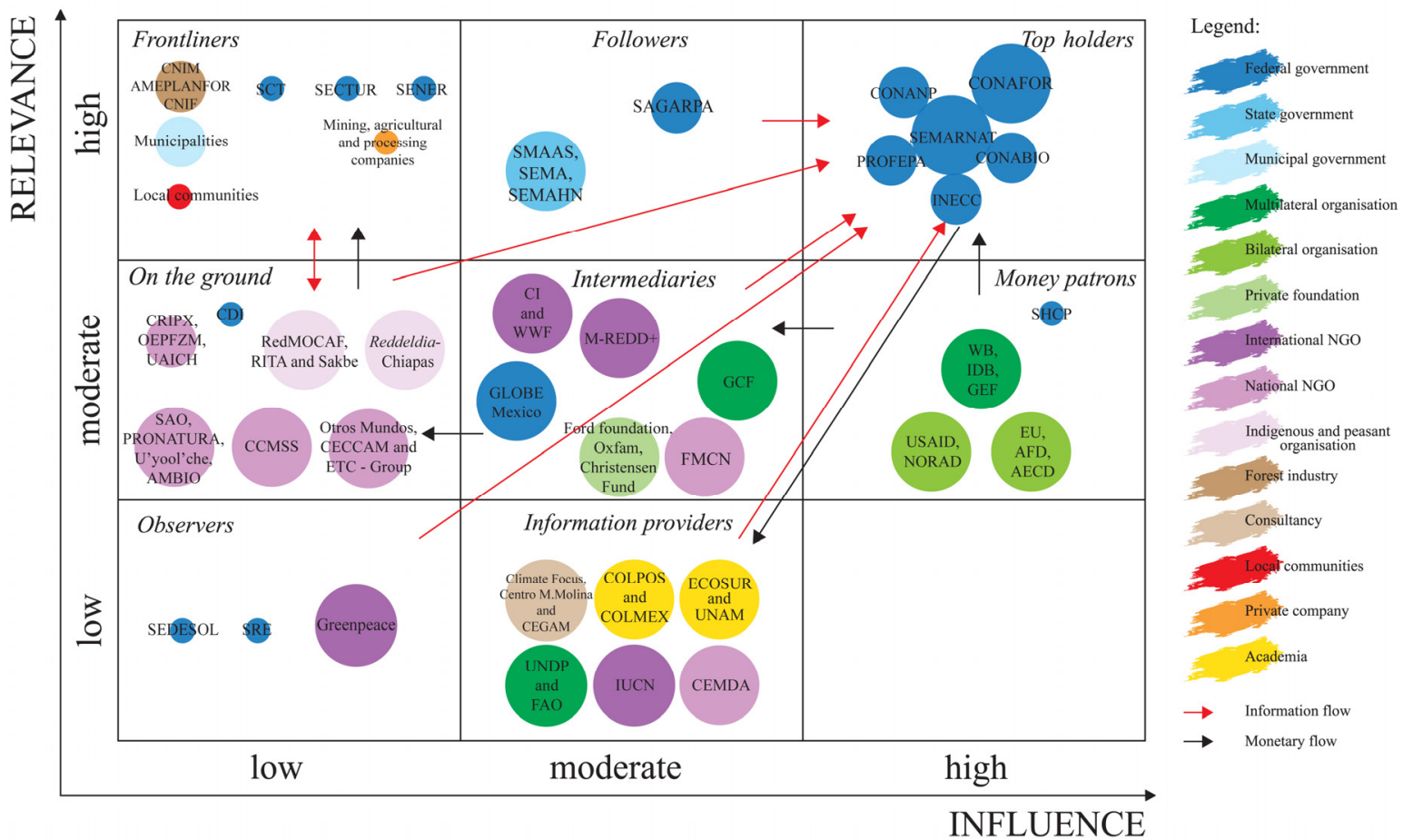

Figure 2. REDD+ stakeholder's groups according to their relevance and influence. Colour corresponds to actor typology (figure right column legend), and size of the circle to the actor's level of interest in REDD+ implementation. Source: own elaboration. SEMARNAT, Ministry of Environment and Natural Resources in Spanish; CONANP, National Commission of Protected Areas; PROFEPA, Office of the Federal Attorney for Environmental Protection; INECC, National Institute of Ecology and Climate Change; CONABIO, National Commission for Knowledge and Use of Biodiversity; SAGARPA, Ministry of Agriculture, Livestock, Rural Development, Fisheries and Food; SMAAS, Ministry of Environment and Sustainable Use, Campeche; SEMA, Ministry of Ecology and Environment, Quintana Roo; SEMAHN, Ministry of Environment and Natural History, Chiapas; SENER, Ministry of Energy; SECTUR, Ministry of Tourism; SCT, Ministry of Communications and Transport; AMEPLANFOR, Mexican Association of Forest Planters; CNIM, National Chamber of Wood Industry; CNIF, National Chamber of Forest Industry; SHCP, Ministry of Finance and Public Credit; WB, World Bank; IDB, Inter-American Development Bank; GEF, Global Environment Facility; EU, European Union; AFD, French Development Agency; AECD, Spanish Agency for International Development Cooperation; USAID, United States Agency for International Development; NORAD, Norwegian Agency for Development Cooperation; GCF, Governors' Climate and Forests Task Force; FMCN, Mexican Fund for the Conservation of Nature; M-REDD+, Mexico REDD+ Alliance; CI, Conservation International; WWF, World Wildlife Fund for Nature; CECCAM, Center for Studies for Change in the Mexican Countryside; ETC-Group, Action Group on Erosion, Technology and Concentration; RedMocaf, Mexican Campesino Forest Producers Network; RITA, Indigenous Network of Environmental Tourisms; CCMSS, Mexican Civil Council for Sustainable Forestry; CRIPX, Popular Regional Indigenous Council of Xpujil; UAICH, Union of Indigenous Beekeepers from Chenes region; OEPFZM, Organization of Forest Ejido Producers of the Maya Zone; SAO, Environmental Services of Oaxaca; CDI, National Commission for Indigenous Development; ECOSUR, College of the South Border; UNAM, National Autonomous University of Mexico; COLPOS, College of Postgraduates; COLMEX, College of Mexico; CEGAM, Centre of Specialists in Environmental Management; CEMDA, Mexican Centre for Environmental Law; IUCN, International Union for Conservation of Nature; UNDP, United Nations Program for Development; FAO, Food and Agriculture Organisation; SEDESOL, Ministry of Social Development; SRE, Ministry of Foreign Affairs. 
Frontliners include a range of actors from different social sectors operating at different geographical and jurisdictional levels, including the Ministries of Tourism (SECTUR), Communications and Transport (SCT), and Energy (SENER); state agricultural agencies; municipal authorities; and some private mining, agricultural, and processing companies and commercial forest plantations (e.g., Asociación Mexicana de Plantadores Forestales (AMEPLANFOR), Cámara Nacional de la Industria Maderera (CNIM), and Cámara Nacional de la Industria Forestal (CNIF)). These actors design or implement policies and activities that influence the country's deforestation rate, which may influence REDD+ success in the future. The group also includes local communities, which own approximately $70 \%$ of the forests [74] and $52 \%$ of the agricultural land in the country [75] and who implement land-use policies and activities on their lands. Frontliners have low influence on REDD+ policy-making due to their limited access to REDD+ financial resources and their lack of information and clear roles in the readiness phase, which has resulted in little involvement and sense of ownership of policy documents. Only municipal authorities and private forest plantations owners participate in REDD+ related events occasionally and are therefore characterised as moderately interested.

Money patrons include moderately relevant actors, such as the World Bank (WB), the InterAmerican Development Bank (IDB), the Global Environment Facility (GEF), and the development agencies of Norway (NORAD), the United States of America (USAID), France (AFD), Spain (AECD), and the federal Ministry of Finance (SHCP). These actors have provided financial resources for the development of REDD+ in Mexico and, in doing so, they have enforced their procedures and timetables. For example, the Mexican government has to follow the FCPF's Strategic Environmental and Social Assessment (SESA) process to meet environmental and social safeguards, as well as it has to respond to the FCPF's timetable in order to be eligible for REDD+ implementation funding under the Carbon Fund in the future. For the same reason, multilateral agencies are considered to be very interested in REDD+. Only the SHCP showed limited interest in participating in REDD+ events.

Intermediaries include the federal agency in charge of legislative power (GLOBE Mexico), a consortium of national and international NGOs (the M-REDD+ Alliance-leader of the "Mexico's REDD+ project" (M-REDD+) including The Nature Conservancy (TNC), Rainforest Alliance (RA), Woods Hole Research Center (WHRC), and Natural Areas and Sustainable Development (ENDESU)), two large international NGOs (World Wildlife Fund (WWF) and Conservation International (CI)), voluntary carbon market developers (e.g., The Californian Governors' Climate and Forests Task Force $(\mathrm{GCF})$ ), and private foundations and funds (e.g., Moore foundation, The Conservation, Food and Health (CFH) foundation, Climate Works). Intermediaries are moderately relevant as they provide knowledge and/or financial resources to the government and/or to actors on the ground for the implementation of pilot REDD+ activities. Such financial resources vest them with a moderate level of influence on REDD+, but given their frequent participation in the readiness phase they have been considered highly interested actors.

On the ground actors include moderately relevant actors who have a role in promoting or facilitating certain land-use and land-change activities at local level. They encompass the National Commission for Indigenous Development (CDI) and numerous civil society organisations (CSOs), such as NGOs developing carbon forestry and/or REDD+ pilot projects (Consejo Mexicano de Silvicultura Sostenible (CCMSS), Servicios Ambientales de Oaxaca (SAO), Cooperativa AMBIO, PRONATURA, and U'yool'che), peasant and indigenous peoples' organisations (Red Mexicana de Organizaciones Campesinas Forestales (RedMocaf), Red Indígena de Turismo (RITA), Sakbe-Comunicación y Defensa), CSOs partners in the Reddeldia-Chiapas movement (e.g., Otros Mundos Chiapas, Centro de Estudios para el Cambio en el Campo Mexicano (CECCAM), Action Group on Erosion, Technology and Concentration (ETC-Group)), and many local CSOs (e.g., Consejo Regional Indígena y Popular de Xpujil (CRIPX), Unión de Apicultores Indígenas de los Chenes (UAICH), Organización de Ejidos Productores Forestales en la Zona Maya (OEPFZM)). These actors neither have important roles in formal decision-making, nor hold significant REDD+ financial resources, therefore have little impact on REDD+ design. However, most members of this 
group participate frequently in REDD+ events, with the exception of CDI and some local CSOs who demonstrate low and moderate interest in REDD+, respectively.

Information providers include national research institutions (Universidad Nacional Autónoma de México (UNAM), El Colegio de la Frontera Sur (ECOSUR), El Colegio de Postgraduados (COLPOS), and El Colegio de México (COLMEX)), two UN agencies (The United Nations Program for Development (UNDP), Food and Agriculture Organisation (FAO)), a large international NGO (International Union for Conservation of Nature (IUCN)), a national NGO (Centro Mexicano de Derecho Ambiental (CEMDA)), and independent expert advisories (Climate Focus, Centro Mario Molina, Centro de Especialistas en Gestión Ambiental (CEGAM)). These actors do not influence land-use change activities and thus will not influence REDD+ effectiveness. They, however, have a role as facilitators and observers of REDD+ readiness and often provide CONAFOR with information on REDD+ technical and governance issues, which makes them moderately influential actors. All information providers are frequent participants in REDD+ readiness and have produced relevant literature on the topic.

Finally, observers include the Ministry of Foreign Affairs (SRE), the Ministry of Social Development (SEDESOL), and the international NGO Greenpeace. The activities of these actors do not affect land-use, so they are considered irrelevant in regards to REDD+ effectiveness. Moreover, these actors have no influence on REDD+ design, as they do not have a specific role in the formal REDD+ decision-making processes nor manage REDD+ financial resources. However, SRE and SEDESOL are considered REDD+ actors because they have helped CONAFOR in negotiating foreign investments for REDD+ and could be important in ensuring that REDD+ activities translate into social co-benefits. Greenpeace is considered a REDD+ actor for its demonstrated high interest in the readiness phase, for participating in the CTC, and for publishing REDD+ related documents.

\subsection{REDD+ Discourses}

We classified REDD+ actors into three discourse coalitions according to their views regarding REDD+'s conceptual and strategic dimensions. Given that a shared degree of relevance, interest, and influence by several actors does not necessarily mean they hold a shared discourse, members of the same stakeholder group might belong to different discourse coalitions. We named each coalition according to its members' general attitude towards REDD+, namely: the opposition, advocacy, and reform coalitions. The reformists' discourse shares some storylines with the advocates and some with the opponents, but the later have no storyline in common and can be considered antagonistic (Figure 3).

The opposition coalition includes numerous CSOs, peasant and indigenous peoples' organisations from Chiapas, and some local communities of the Lacandon rainforest implementing REDD+ pilot projects, members of frontliners, and on the ground stakeholder groups. The shared discourse of this coalition is that REDD+ is not the solution to climate change because deforestation is not its main driver and because REDD+ potentially allows the global North to offset its greenhouse gas emissions cheaply in the global South, instead of reducing domestic emissions or paying off a climate debt. Opponents warn that REDD+ may introduce changes in forest tenure rights that could constrain local people's access to forest resources and lead to the loss of local knowledge and forest conservation behaviours. Overall, in the opposition coalition storylines, local communities are characterised as both heroes and losers in REDD+, while the government, private companies, financial institutions, and large international NGOs are seen as culprits and winners. Opponents argue that the process of consulting with local people in the REDD+ readiness phase has been subject to moral manipulation:

"They [the government] say to the communities: ... we are fighting climate change, and we will pay you to help. Are you with us? The expected answer is: Of course we are." (representative of Otros Mundos Chiapas in [76]). 
Opponents

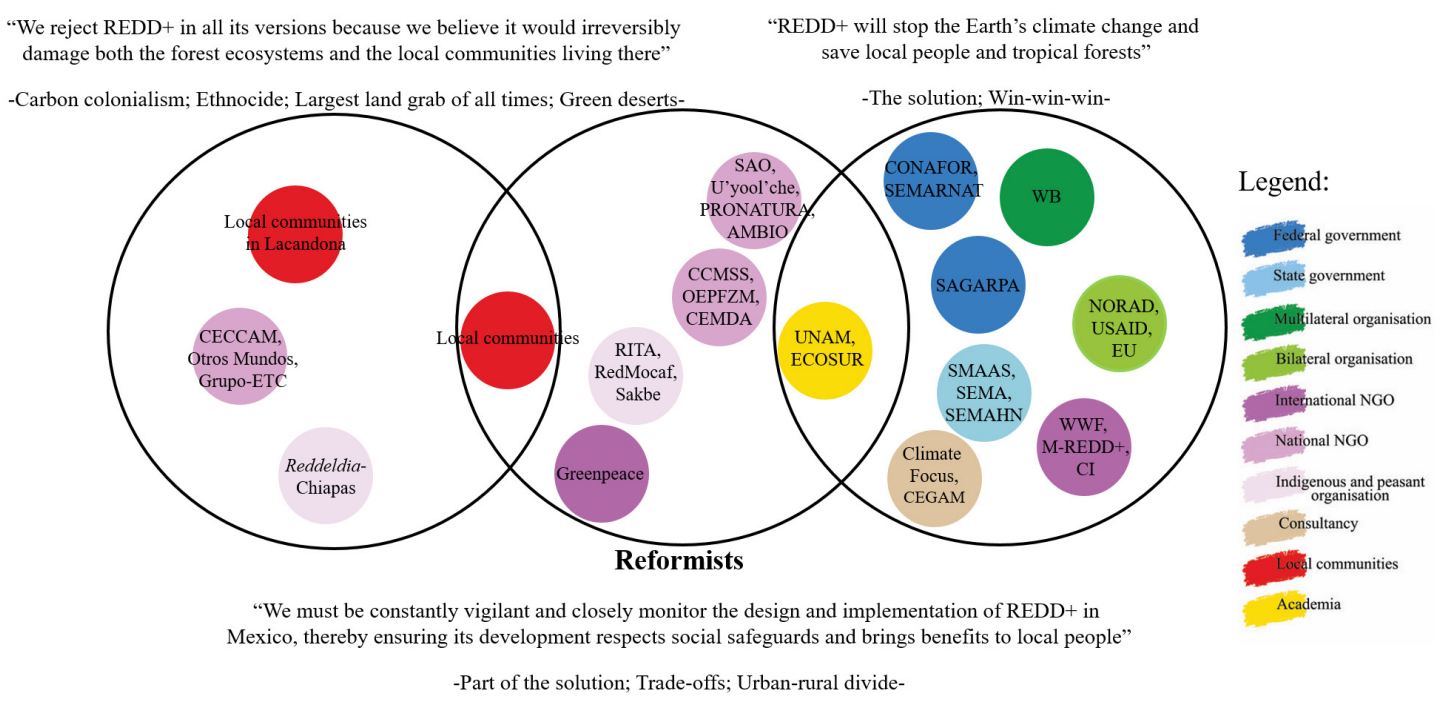

Figure 3. Composition (non-exhaustive) of the three REDD+ discourse coalitions in Mexico. The overlaps represent storylines on specific REDD+ issues shared between discourse coalitions. Each coalition is described by key metaphors and a quote paraphrased from interviews and documents to summarise the main storylines. Source: own elaboration.

Opponents do not participate in official REDD+ forums, which they consider illegitimate. However, they use informal mechanisms such as alternative forums, protests, campaigns, official letters, and printed and video material to call for structural changes to address deforestation and forest degradation (e.g., [77-81]). They maintain that community-based forest management founded upon democratic consultation is a viable alternative to REDD+.

Advocates include representatives of federal and sub-national government ministries and agencies, as well as multilateral and bilateral organisations and carbon market developers, and international NGOs and consultancies. These are in most part members of top holders, followers, money patrons, and intermediaries stakeholder groups. Advocates consider REDD+ as an opportunity to bring economic, social, and environmental co-benefits to rural communities that might help solve deforestation and forest degradation in developing countries. In the advocates' view, deforestation drivers in Mexico include unsound land-use policies, uncontrolled urban and tourism infrastructure development, and illegal logging, all activities in which local communities participate.

Most advocates generally prefer a national approach to REDD+, as it allows a centralised control of REDD+ funding. However, under the current slow and uncertain development of UNFCCC's negotiations, advocates would also favour a jurisdictional approach that could facilitate the development of REDD+ activities at the scale of administrative units or eco-regions. Advocates support a landscape-based approach to REDD+ implementation that could bring benefits to individuals or groups of forest owners, such as payment for ecosystem services (PES) initiatives coordinated with productive activities under the umbrella of sustainable rural development.

In the advocates' view, any potential benefit accruing from the enhancement of forests' carbon stocks should be directed to forest owners, while benefits from emission reductions from avoided deforestation should be attributed to the government. This is because it is not legally possible to assign a property right over something that has never existed (i.e., emissions reductions are essentially the product of performance against a hypothetical reference level baseline) and because deforestation is illegal unless government authorised. As this interviewee notes:

"Under the current legal framework, any change in land-use has to be authorised. Therefore if a person says: I will deforest; it is the same as if he says: I will kill three people, but if I instead kill only one, you have to compensate me." (INECC officer, 05 February 2014). 
Advocates suggest that the voluntary nature of REDD+ and the widespread legitimacy of Mexico's land tenure regime should guarantee the alignment of REDD+ activities with the UNFCCC social safeguards. Advocates understand safeguards as rights and duties that REDD+ actors should respect. They also perceive the CTC as a legitimate forum that has included all key actors and has been transparent in providing information. Advocates argue that, given the high costs of involving local peoples in federal and state decision-making processes, the lack of local communities' participation in the CTC is an intrinsic problem of environmental decision-making in Mexico and beyond.

The reformists' coalition involves national NGOs, peasant and indigenous peoples' organisations, and local communities' members of on the ground and frontliners stakeholder groups, as well as representatives of academia from information providers and one international NGO from the observers group. Reformists support REDD+ as an important element of national climate change policy, but do not consider deforestation as the largest source of greenhouse gas emissions. According to the reformists, REDD+ has the potential to provide positive benefits to local communities, but only if it promotes sustainable rural development that combines conservation and productive activities. Reformists argue that over-consumption of natural resources by urban populations, contradictory agricultural subsidies, and urban and tourism infrastructure development should be simultaneously tackled to stop deforestation.

In the early readiness phase, all reformists, except the academic sector, preferred a jurisdictional over a national REDD+ approach, arguing that the jurisdictional approach would ease the identification and attribution of responsibility to all actors contributing to deforestation in the selected regions, and not only to local communities, mistaken as the main culprits. Reformists also consider that the rights over forests' carbon stocks and over the reduction of emissions from avoided deforestation should be recognised as an ecosystem service in the national legal framework and linked to land ownership. For this reason, the peasant and indigenous peoples' organisations in this coalition oppose a landscape approach to REDD+:

“... if I take care of my forest but my neighbour gives his forest to a mining concession and therefore causes deforestation, the overall [carbon stock and emission reductions] measurements in a given territory will be affected. It is then a question of carbon ownership." (RITA officer, 6 February 2014).

In line with the advocates, reformists suggest that the legitimacy of the current land tenure regime guarantees that REDD+ does not contribute to alienate land rights in Mexico. However, they emphasise that REDD+ policies and measures should respect international laws and conventions on human and indigenous peoples' rights, and that solid social safeguards should guide REDD+ design and implementation.

There are different positions among reformists regarding the legitimacy of REDD+ decision-making. Large national NGOs and academia consider the CTC inclusive and therefore a legitimate forum. Others, mostly peasant and indigenous peoples' organisations, left the CTC to push for the establishment of GT-ENAREDD+ because, in their opinion, the former lacks inclusiveness, transparency, and accountability. The local communities from our sample did not participate in national REDD+ discussions.

\subsection{Degree of Discourse Influence}

Our analysis suggests that the advocates' discourse is 'dominant' as it has all the storylines on both conceptual and structural REDD+ issues explicitly acknowledged in the fifth ENAREDD+ draft and the ER-PIN (i.e., it reaches the highest degree of structuration and institutionalisation). The reformists' discourse is 'marginalised' in regards to conceptual issues, with only one of its storylines present in these documents, but partially institutionalised in regards to strategic issues, since four of its related storylines are represented in the named documents. Finally, the opponents' discourse is the most 'marginalised' and has the lowest degree of structuration and institutionalisation, because none of its storylines have been identified in the national REDD+ documents (Figure 4; Table 4). 
Table 4. Quotes related to the ten key REDD+ issues extracted from the analysed documents and paraphrased for length. Source: own elaboration from the sources indicated in the Table. FCPF, Forest Carbon Partnership Facility; PES, payment for ecosystem services.

\begin{tabular}{|c|c|}
\hline Key REDD+ Issues & Official REDD+ Statements \\
\hline REDD + goals and role & $\begin{array}{l}\text { Deforestation is the third largest source of carbon emissions in the country and } \\
\text { worldwide [54] (pp. 11, 20). } \\
\text { Any disturbance of tropical forests significantly affects the global carbon cycle and } \\
\text { contributes to climate change [54] (p. 12). } \\
\text { Mexico has a great potential for REDD+ not only for reducing deforestation and } \\
\text { forest degradation, but also for increasing forest carbon stocks [54] (p. 22). }\end{array}$ \\
\hline Deforestation drivers & $\begin{array}{l}\text { The main drivers of deforestation in the country are unsound agricultural policies } \\
\text { followed by tourism, urban and industrial development; lack of coordination } \\
\text { across these land-use sectors, and ineffective legislation [54] (p. 20); [55] (p. 28). } \\
\text { Forest owners have few incentives to preserve them due to the market demand for } \\
\text { specific products (e.g., timber, minerals, food, meat, biofuels, etc.), local needs, and } \\
\text { population growth [55] (p. 27). }\end{array}$ \\
\hline $\begin{array}{l}\text { Local people } \\
\text { and deforestation }\end{array}$ & $\begin{array}{l}\text { Greater deforestation occurs in communities without forest management } \\
\text { institutions [55] (p. 28). } \\
\text { Forest degradation is caused by local forest users' activities (e.g., selective } \\
\text { harvesting, overgrazing, extraction of firewood, etc.) [55] (p. 26). }\end{array}$ \\
\hline Implementation scale & $\begin{array}{l}\text { The FCPF Carbon Fund pays for emission reductions to the National Fund, which } \\
\text { transmits the sum (proportionally according to emissions reduction contribution) } \\
\text { to a jurisdictional fund (state or interstate fund) [54] (p. 46); [55] (pp. 34, 64). }\end{array}$ \\
\hline Benefit-sharing strategy & $\begin{array}{l}\text { The scale of activities under REDD+ corresponds to a territory that includes } \\
\text { a number of communities and obeys environmental limits (basin, sub-basin, } \\
\text { biological corridor) [55] (p. 33). }\end{array}$ \\
\hline Scope of activities & $\begin{array}{l}\text { Sustainable rural development is the best way to realise REDD+ in } \\
\text { Mexico [54] (pp. 26, 33). } \\
\text { PES is one of the activities within the special programmes [55] (pp. 31-33). } \\
\text { REDD+ offers new opportunities to effective management and expansion of } \\
\text { protected areas to contribute to climate change mitigation [54] (p. 25). } \\
\text { Community forest management can be more effective in controlling deforestation } \\
\text { than protected areas [55] (pp. 31-33). } \\
\text { Sustainable agricultural practices could be part of REDD+ [55] (p. 33). }\end{array}$ \\
\hline Co-benefits & $\begin{array}{l}\text { Co-benefits or collateral benefits refer to the additional benefits to carbon storage } \\
\text { resulting from REDD+ implementation, such as poverty reduction, biodiversity } \\
\text { conservation and improvement in forest governance [54] (p. 86). } \\
\text { REDD+ in Mexico will generate substantial non-carbon benefits because it will be } \\
\text { implemented in early action regions [55] (pp. } 2,30,63 \text { ). }\end{array}$ \\
\hline Social safeguards & $\begin{array}{l}\text { Safeguards are designed to prevent and mitigate any direct or indirect negative } \\
\text { impact on ecosystems and local people [54] (pp. 67-68). } \\
\text { REDD+ is of voluntary nature and a collective consent by community authorities } \\
\text { will guarantee respect of social safeguards [55] (p. 80). } \\
\text { Safeguard Information System and Safeguard National System should oversee } \\
\text { safeguards implementation and respect [54] (p. 70); [55] (p. 14). }\end{array}$ \\
\hline Land tenure & $\begin{array}{l}\text { Mexico has a sound community land rights system, therefore there is little risk of } \\
\text { land rights violations [55] (p. 36). }\end{array}$ \\
\hline Carbon rights & $\begin{array}{l}\text { The ownership over biomass and carbon stocks is in the hands of forest owners, } \\
\text { as sanctioned by national legislation (Art. 134bis, General Law of Sustainable } \\
\text { Forest Development). However, it is not legally or technically feasible to attribute } \\
\text { emissions reductions that result from avoided deforestation to a particular forest } \\
\text { owner within the landscape, who might only hold the rights [not the ownership] to } \\
\text { benefit from these emissions reduction [54] (p. 35); [55] (p. 36). } \\
\text { Avoided deforestation has not been defined as an environmental service in } \\
\text { any legislation to date. If necessary, corresponding law reforms should be } \\
\text { promoted [54] (p. 35). }\end{array}$ \\
\hline
\end{tabular}




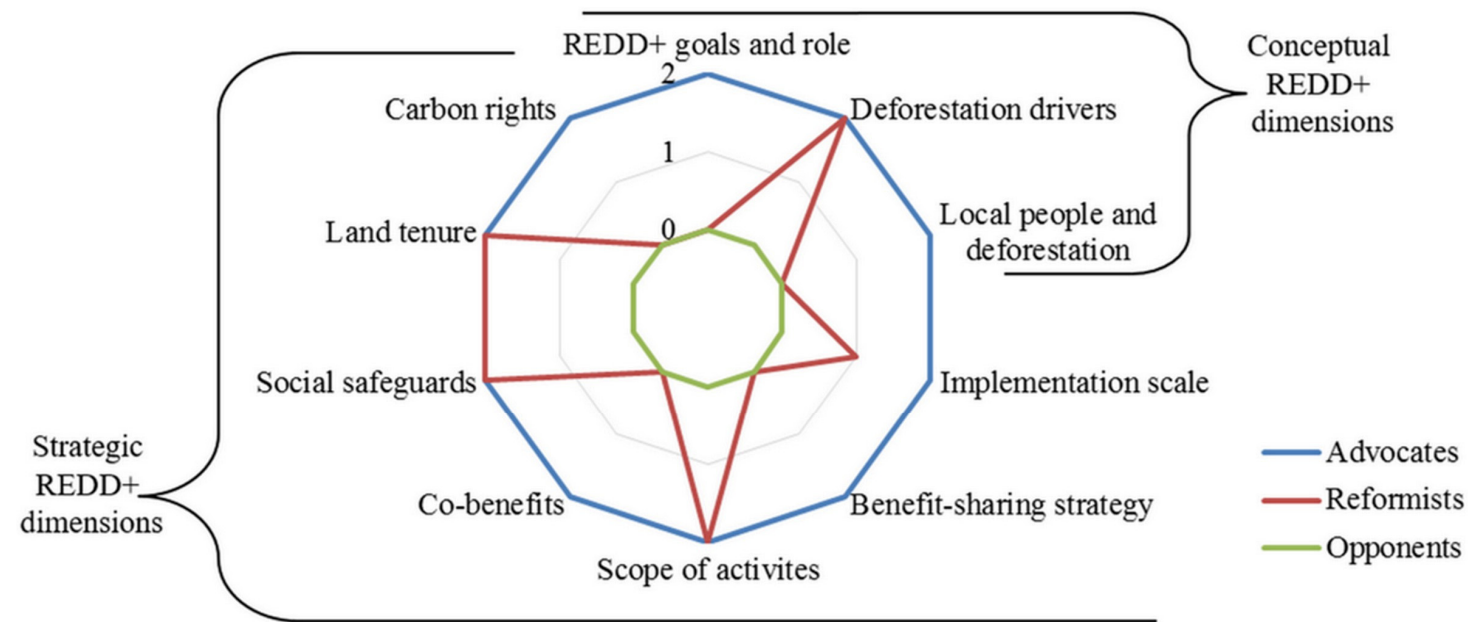

Figure 4. Degree of structuration and institutionalisation of the central storylines on ten key REDD+ dimensions. 0 , no storyline included in the REDD+ documents; 1, storyline implicitly included; 2, storyline explicitly included. Source: own elaboration.

In line with the reformists' storyline, the REDD+ documents analysed in this article present deforestation as the third largest source of carbon emissions, but in line with the advocates' storyline, they also sustain an explicit connection between climate change mitigation and the need to preserve tropical forests. REDD+ is also presented as a key national mitigation measure, the implementation of which will guarantee non-carbon benefits. These documents also suggest that the key underlying drivers of deforestation in Mexico are ineffective legislation and uncoordinated land-use policies, as suggested by both advocates and reformists. In addition, the documents implicitly consider the critical impact on deforestation of the growing urban population's demand of agricultural goods and forest resources, as noted in the reformists' storyline. Nevertheless, the documents implicitly address the advocates' storyline on local people's responsibility in causing or halting deforestation by emphasising the importance of forest owners' capacities and incentives to use sustainably their forests, as well as by explicitly identifying local communities as key forest degradation agents.

According to the ENAREDD+ and the ER-PIN documents, REDD+ in Mexico will be operationalised through a set of activities from various land-use sectors with sustainable rural development as a leading principle, as suggested by the reformists' storyline. Potential REDD+ activities include PES, the establishment of protected areas, and sustainable agricultural practices, suggested by advocates, as well as activities oriented to community forest management, vehemently promoted by the reformists. These activities will be operationalised in "REDD+ implementing landscapes" and the ensuing verified carbon emission reductions would be accounted for at a jurisdictional level (state or region) and traded through a national government entity, as supported by the advocates' storyline.

Further, in line with the reformists' idea, and in addition to the Cancun Agreements' safeguards [26] the fifth ENAREDD+ draft and the ER-PIN include the so called 'national safeguards'. Both documents emphasise the voluntary nature of REDD+ activities and the fact that a collective consent obtained from community authorities should be enough to guarantee respect of social safeguards, as in the advocates' storyline. However, by promoting the elaboration of the Safeguard Information System and Safeguard National System that should oversee the implementation and respect of the safeguards, the documents also include reformists' concerns on this issue and the importance of respecting communities' land tenure and other customary rights. Yet again, and in line with both the advocates' and the reformists' discourse, the documents assert that REDD+ implementation should not challenge land ownership nor facilitate land grabbing. 
Most importantly, and as included in the advocacy coalition storyline, the two analysed documents propose that forest owners hold full ownership over existing carbon stocks and expected carbon gains, while they are only entitled with the rights to benefit from potential emission reductions from avoided deforestation on their lands. This decision is explained by the critical technical difficulties to attribute emission reductions from such activities to one forest owner.

Based on the actors' perceptions of the national REDD+ discussions organised through the CTC and the identified degrees of discourse influence, we suggest that the current REDD+ readiness process in Mexico is considered legitimate, both from an input and output perspective, only by members of the 'dominant' REDD+ advocacy coalition, which include national and sub-national government agencies, international NGOs, multilateral and bilateral organisations, and consultancies. Other actors, including some national NGOs and academic institutions, have considered the process legitimate from a decision-making perspective, but not from an output perspective due to the fact that policy documents have been unable to integrate some of their central ideas on key REDD+ issues. More worrisome is the fact that some national NGOs and peasant indigenous peoples' organisations from the reform coalition and all members of the opposition coalition consider REDD+ illegitimate from an input perspective and refuse to grant REDD+ readiness in Mexico with output legitimacy (Figure 5).

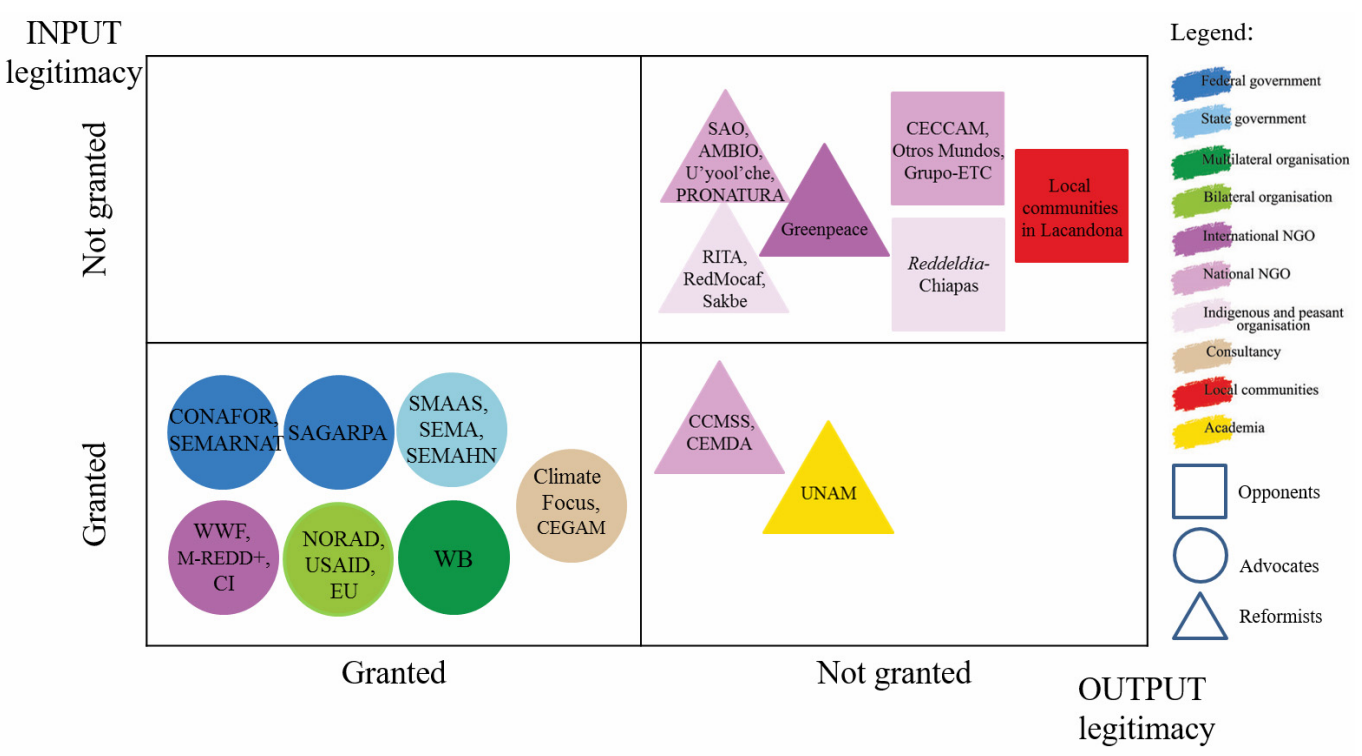

Figure 5. Correlation between the actors' sector, discourse, and perception on the input and output legitimacy of REDD+ governance in Mexico. Source: own elaboration.

\section{Discussion}

The results above suggest that Mexico's REDD+ readiness process has included to date a variety of actors differing in relevance, influence, and interest. Not surprisingly, the highest capacity to influence REDD+ policy development has lied in the federal government, and particularly in its forestry agency. The latter has justified its control over the REDD+ policy-making process by portraying itself as more capable and reliable authority than sub-national counterparts [82]. Notwithstanding, our research suggests that there has been a limited or almost negligible involvement from other ministries in REDD+ readiness, which could possibly compromise the effectiveness of REDD+ activities in the future.

CONAFOR has shared some decision-making power in REDD+ with academia and international NGOs hired to provide guidance on REDD+ technical and governance issues. However, national NGOs have remained sceptical about the input legitimacy of the REDD+ readiness process [83], considering it a government- and donor-driven process without the meaningful representation of local communities $[84,85]$. Similarly, non-governmental REDD+ actors in Indonesia have also perceived the national readiness process as externally driven and even detrimental for national sovereignty [36]. 
Although local communities' low capacity to influence REDD+ readiness has also been found in most developing countries participating in REDD+ [28,35], it is particularly worrisome in a country where rural communities have rights over the majority of forests and agricultural lands $[74,75]$. Lack of local community involvement can undermine the interest of national NGOs and peasant and indigenous peoples' organisations in the policy process in the future, which would not be a surprising outcome [86]. In the Democratic Republic of the Congo, for example, a group of national NGOs suspended their engagement with the REDD+ coordination process in 2012 [87], and an indigenous peoples' coordinating body withdrew from the Panama's REDD+ readiness process in 2013 [88]. In Mexico, the fact that some organisations left the CTC in disconformity and began to articulate their claims in an alternative forum under CONAF might be regarded both as a complaint to the ongoing process or as a strategic move to open new grounds for broader participation and deliberation [89] (see last paragraph in Section 3.1).

The legitimacy of governance processes is a dynamic state that must be constantly created and recreated among all participants $[24,90]$. This process implies the need to design REDD+ multi-stakeholder forums flexible enough to guarantee their credibility and legitimacy. In Mexico, the government justified the absence of practical solutions to increase the level of input legitimacy of the readiness process on the grounds that key national and international NGOs already endorsed the CTC-driven process. Yet the fragmentation of the national REDD+ discussion in two national forums revealed the fragility of the decision-making procedures governing the CTC. Subsequently, the lack of clarity regarding how deliberations in both forums had to feed into the national strategy resulted in confusion and ultimately resulted in the government prioritising the views and inputs from those participating in the CTC.

Our results also indicate that Mexico's REDD+ readiness actors have mobilised numerous storylines around which the three identified discourse coalitions have coalesced. The principal differences between the three coalitions reflect divergent perspectives around REDD+ conceptual dimensions and that the advocacy and reform coalitions differ in their views about strategic REDD+ issues, particularly regarding the attribution of carbon rights (for similar findings see references [91-93]). Not surprisingly, the advocates' discourse is 'dominant' in the analysed REDD+ readiness documents, given that this is the discourse promoted by CONAFOR. The dominance of a government-supported discourse has also been found in other REDD+ host countries, including Tanzania [92], Mozambique [93], Indonesia, Brazil, Vietnam, Peru [94], and Nepal [37].

Although it would be tempting to assume that under the 'dominant' coalition there would be little room for alternative arguments, some of the exclusively reformists' arguments have found their way into Mexico's REDD+ documents, although the reasons for this seem to be highly contextual. The adoption of safeguards and a jurisdictional approach can be explained by the impact of the global REDD+ debate on the Mexican government's views, whereas the adoption of the sustainable rural development principle and the existence of technical and not only legal difficulties to the attribution of carbon rights at the forest owner's level can be attributed to the government's alignment with the argument promoted by some reformists.

A high level of output legitimacy does not imply an even translation of actors' ideas into policy decisions [95], but rather that most actors have a strong sense of ownership over the decisions adopted [96]. In this regard, our analysis reflects that the documents include only a limited number of alternative storylines, while many in the reformists' coalition still support the fifth ENAREDD+ draft to be sent for a countrywide public consultation (ongoing at the time of writing). After all, large national NGOs perceive the REDD+ decision-making process as legitimate, while other national NGOs and peasant and indigenous organisations think that involving local people more directly is critical to legitimate REDD+ implementation in the coming future.

The case of the opposition coalition is different. It is not surprising that members of this coalition have not endorsed the REDD+ readiness process, principally because they are against some of the REDD+ conceptual dimensions promoted by the other two coalitions, such as the role of forests as carbon sinks, the supposedly secure status of Mexico's tenure regime, or the lack of risk of land grabs 
by external actors. The informal forums, protests, and campaigns that these actors have organised have proved ineffective to persuade the government to abandon the REDD+ process but, in the future, it seems plausible to think that this coalition will play a critical role in overseeing and scrutinising REDD+ implementation.

\section{Conclusions}

This paper set out to explore the legitimacy of the REDD+ readiness process in Mexico by analysing REDD+ actors' characteristics and their participation in the related decision-making process (i.e., input legitimacy), and by calculating the degree to which the different actors' ideas are reflected in the resulting official REDD+ policy documents (i.e., output legitimacy). Our results corroborate an existing trend in national REDD+ governance of increasing centralisation of REDD+ policy making and early implementation $[18,97]$ in which the predominant actors are the government, donors, international INGOs, and select CSOs [36,98]. In addition, the design of the correspondent multi-stakeholder forums has been ineffective in bringing forward the perspectives of sub-national and other non-governmental stakeholders [31,98-100]. As other REDD+ pursuing countries, Mexico continues to face the challenge of designing and establishing a legitimate REDD+ readiness process that includes, on an equal basis, a variety of actors in the decision-making process and that acknowledges the actors' diverse views, communicated through different discourses, in REDD+ policy documents.

To improve the legitimacy of REDD+ readiness process, Mexico and other REDD+ host countries should consider designing novel institutional arrangements under a more inclusive and decentralised approach and strengthening the coordination among the existing multi-stakeholder forums. Greater inclusiveness of a more diverse range of public policy sectors and non-state actors, particularly local communities' representative organisations, at both national and sub-national levels, would enrich REDD+ discussions and improve the quality of the national strategy design with alternative storylines, such as those on locally adequate and acceptable REDD+ activities. In this sense, the countrywide public consultation of the ENAREDD+ draft conducted very recently suggests that the Mexican government was well aware of the need to broaden the scope of the participatory process analysed in this article.

We believe, however, that the ensuing REDD+ implementation phase would require additionally efforts to ensure that legitimacy increases. Promoting a greater number of public debates across governance scales to further discuss the advantages and risks of REDD+ activities on the ground, including their possible impact on local tenure systems and ecosystem services management regimes, as well as an equitable benefit-sharing of resulting emission reductions (currently under design) seems a promising way forward. Only by including alternative viewpoints and constructive proposals on these and other issues might Mexico and other REDD+ host countries limit the scope of social contestation and guarantee a higher degree of legitimacy in the operation of such ambitious policy framework.

Acknowledgments: The authors acknowledge two anonymous reviewers, Arild Angelsen, Roser Maneja and Diana Pritchard for constructive comments on an earlier version of this manuscript. Jovanka Špirić acknowledges the financial support received from the FI-AGAUR scholarship of the Catalan government, the Fundació Autònoma Solidària cooperation grant, the Foundation Open Society Institute's Global Supplementary Grants, as well as the additional financial and logistical support from the EU projects: CONSERVCOM funded by Fondo de Cooperación Internacional en Ciencia y Tecnología UE-México (FONCICYT 94395) and Programa de Cooperación Inter-Universitaria e Investigación Científica, Ministerio de Asuntos Exteriores y Cooperación (A/023406/09 and A/030044/10), and COMBIOSERVE (Grant No. 282899). Esteve Corbera acknowledges the financial support of the 'Conflict and Cooperation over REDD+ in Mexico, Nepal and Vietnam' project, supported by the Netherlands Organisation for Scientific Research and the UK Department for International Development (Grant No W07.68.415), as well as of the UAB-Banco de Santander Talent Retention Programme. This work contributes to ICTA-UAB "María de Maeztu Unit of Excellence" (MDM-2015-0552).

Author Contributions: Jovanka Špirić designed the research with inputs from Esteve Corbera, Victoria Reyes-García, and Luciana Porter-Bolland. Jovanka Špirić collected and analysed the data. All authors participated in writing the paper.

Conflicts of Interest: The authors declare no conflict of interest. 


\section{References}

1. Corbera, E.; Schroeder, H. Governing and implementing REDD+. Environ. Sci. Policy 2011, 14, 89-99. [CrossRef]

2. Thompson, M.C.; Baruah, M.; Carr, E.R. Seeing REDD+ as a project of environmental governance. Environ. Sci. Policy 2011, 14, 100-110. [CrossRef]

3. Lederer, M. REDD+ governance. WIREs Clim. Chang. 2012, 3, 107-113. [CrossRef]

4. Vignola, R.; Guerra, L.; Trevejo, L.; Aymerich, J.P. REDD+ Governance across Scales in Latin America. Perceptions of the Opportunities and Challenges from the Model Forest Platform; REDD-Net Publications: London, UK, 2012. Available online: http://repositorio.bibliotecaorton.catie.ac.cr/bitstream/handle/11554/8285/REED_ Governance_across_scales_in_Latin_America.pdf (accessed on 14 April 2016).

5. Long, A. REDD+, Adaptation, and sustainable forest management: Toward effective polycentric global forest governance. Trop. Conserv. Sci. 2013, 6, 384-408. [CrossRef]

6. De la Plaza, C.; Visseren-Hamakers, I.J.; De Jong, W. The legitimacy of certification standards in climate change governance. Sustain. Dev. 2014, 22, 420-432. [CrossRef]

7. United Nations Collaborative Programme on REDD+ (UN-REDD+). Programme Regions and Partner Countries. 2016. Available online: http:/ /www.un-redd.org/partner-countries (accessed on 12 July 2016).

8. Forest Carbon Partnership Facility (FCPF) REDD+ Countries. 2016. Available online: https://www. forestcarbonpartnership.org/redd-countries-1 (accessed on 12 July 2016).

9. Davis, C.; Nakhooda, S.; Daviet, F. Getting Ready. A Review of the World Bank Forest Carbon Partnership Facility Readiness Preparation Proposals; Version 1.3; WRI Working Paper; World Resources Institute: Washington, DC, USA, 2010. Available online: http:/ / www.wri.org/gfi (accessed on 6 August 2016).

10. Bradley, A. Review of Cambodia's REDD Readiness: Progress and Challenges, Forest and Conservation Project; Occasional Paper No. 4; Institute for Global Environmental Studies: Hayama, Japan, 2011. Available online: http:/ / redd-database.iges.or.jp/redd/download/link?id=4 (accessed on 6 August 2016).

11. United Nations Framework Convention on Climate Change (UNFCCC). Report of the Conference of the Parties on Its Nineteenth Session, Held in Warsaw from 11 to 23 November 2013. Available online: http://unfccc.int/resource/docs/2013/cop19/eng/10a01.pdf (accessed on 1 August 2016).

12. Cadman, T.; Maraseni, T.N. The governance of REDD+: An institutional analysis in the Asia Pacific region and beyond. J. Environ. Plan. Manag. 2011, 55, 617-635. [CrossRef]

13. Cadman, T.; Maraseni, T.N. More equal than others? A comparative analysis of state and nonstate perceptions of interest representation and decisionmaking in REDD+ negotiations. Eur. J. Soc. Sci. Res. 2013, 26, 214-230. [CrossRef]

14. Maraseni, T.N.; Cadman, T. Comparative analysis of global stakeholders' perceptions of the governance quality of the CDM and REDD+. Int. J. Environ. Stud. 2015, 72, 288-304. [CrossRef]

15. United Nations Framework Convention on Climate Change (UNFCCC). Document FCCC/CP/2010/7/Add.1, Report of the Conference of the Parties Fifteenth Session, Held in Copenhagen from 7 to 19 December 2009. Available online: http://unfccc.int/resource/docs/2010/cop16/eng/07a01.pdf (accessed on 1 August 2016).

16. Lyster, R. REDD+, transparency, participation and resource rights: The role of law. Environ. Sci. Policy 2011, 14, 118-126. [CrossRef]

17. United Nations Collaborative Programme on REDD+ (UN-REDD+). Legal Analysis of Cross-Cutting Issues for REDD+ Implementation. Lessons Learned from Mexico, Viet Nam and Zambia, 2013. UN-REDD Programme Secretariat International Environment House: Geneva, Switzerland. Available online: http:/ /theredddesk.org/ sites/default/files/resources/pdf/2013/legal-analysis-final-web_1.pdf (accessed on 3 September 2016).

18. Cadman, T.; Maraseni, T.; López-Casero, F.; Ok Ma, H. Governance values in the climate change regime: Stakeholder perceptions of REDD+ legitimacy at the national level. Forests 2016, 7, 212. [CrossRef]

19. Scharpf, F. Governing in Europe. Effective and Democratic; Oxford University Press: Oxford, UK, 1999.

20. Bäckstrand, K. Multi-stakeholder partnerships for sustainable development: Rethinking legitimacy, accountability and effectiveness. Eur. Environ. 2006, 16, 290-306. [CrossRef]

21. Paavola, J. Institutions and environmental governance: A reconceptualization. Ecol. Econ. 2007, 63, 93-103. [CrossRef] 
22. Vatn, A.; Vedeld, P. National governance structures for REDD+. Glob. Environ. Chang. 2013, 23, 422-432. [CrossRef]

23. Burger, D.; Mayer, C. Making Sustainable Development a Reality: The Role of Social and Ecological Standards; Deutsche Gesellschaft für Technische Zusammenarbeit: Kessel, Germany, 2003; p. 50. Available online: http:/ /www.mekonginfo.org/assets/midocs/0002193-economy-making-sustainable-development-areality-the-role-of-social-and-ecological-standards.pdf (accessed on 6 August 2016).

24. Parkinson, J. Deliberating in the Real World: Problems of Legitimacy in Deliberative Democracy; Oxford University Press: Oxford, UK, 2006.

25. Vatn, A. Environmental Governance-A Conceptualization. In The Political Economy of Environment and Development in a Globalized World. Exploring the Frontiers; Kjosavik, D., Vedeld, P., Eds.; Tapir Academic Press: Trondheim, Norway, 2011; pp. 131-152.

26. United Nations Framework Convention on Climate Change (UNFCCC). The Cancun Agreements. 2010. Available online: http://unfccc.int/resource/docs/2010/cop16/eng/07a01.pdf (accessed on 6 August 2016).

27. Angelsen, A. Moving ahead with REDD: Issues, Options and Implications; Center for International Forestry Research: Bogor, Indonesia, 2008. Available online: http:/ /www.cifor.org/publications/pdf_files/Books/ BAngelsen0801.pdf (accessed on 6 August 2016).

28. Veierland, K. Inclusive REDD+ in Indonesia? A Study of the Participation of Indigenous People in the Making of the National REDD+ Strategy in Indonesia; University of Oslo: Oslo, Norway, 2011.

29. Angelsen, A.; Brockhaus, M.; Sunderlin, W.D.; Verchot, L.V. Analysing REDD+: Challenges and Choices; Center for International Forestry Research: Bogor, Indonesia, 2012. Available online: http:/ /www.cifor.org/ publications/pdf_files/Books/BAngelsen1201.pdf (accessed on 6 August 2016).

30. Aquino, A.; Guay, B. Implementing REDD+ in the Democratic Republic of Congo: An analysis of the emerging national REDD+ governance structure. For. Policy Econ. 2013, 36, 71-79. [CrossRef]

31. Manyika, K.F.K.; Kajembe, G.C.; Silayo, D.A.; Vatn, A. Strategic power and power struggles in the national REDD+ governance process in Tanzania: Any effect on its legitimacy? Tanzan. J. For. Nat. Conserv. 2013, 83, 69-82.

32. Mulyani, M.; Jepson, P.R. REDD+ and forest governance in Indonesia: A multistakeholder study of perceived challenges and opportunities. J. Environ. Dev. 2013, 22, 261-283. [CrossRef]

33. Somorin, O.A.; Visseren-Hamakers, I.J.; Arts, B.; Sonwa, D.J.; Tiani, A.-M. REDD+ policy strategy in Cameroon: Actors, institutions and governance. Environ. Sci. Policy 2014, 35, 87-97. [CrossRef]

34. Zelli, F.; Erler, D.; Frank, S.; Hein, J.I.; Hotz, H.; Cruz-Melgarejo, A.M.S. Reducing Emissions from Deforestation and Forest Degradation (REDD) in Peru: A Challenge to Social Inclusion and Multi-Level Governance; German Development Institute: Bonn, Germany, 2014.

35. Minang, P.A.; Van Noordwijk, M.; Duguma, L.A.; Alemagi, D.; Do, T.H.; Bernard, F.; Agung, P.; Robiglio, V.; Catacutan, D.; Suyanto, S.; et al. REDD+ Readiness progress across countries: Time for reconsideration. Clim. Policy 2014, 14, 685-708. [CrossRef]

36. Luttrell, C.; Resosudarmo, I.A.P.; Muharrom, E.; Brockhaus, M.; Seymour, F. The political context of REDD+ in Indonesia: Constituencies for change. Environ. Sci. Policy 2014, 35, 67-75. [CrossRef]

37. Khatri, D.B.; Pham, T.T.; Di Gregorio, M.; Karki, R.; Paudel, N.S.; Brockhaus, M.; Bhushal, R. REDD+ politics in the media: A case from Nepal. Clim. Chang. 2016, 138, 309-323. [CrossRef]

38. Forest Carbon Partnership Facility (FCPF). Readiness Plan Idea Note (R-PIN)_External Review Form, Mexico. 2008. Available online: https://www.forestcarbonpartnership.org/sites/forestcarbonpartnership. org/files/Mexico_TAP_Consolidated.pdf (accessed on 6 August 2016).

39. Comisió Nacional Forestal (CONAFOR). The Forest Carbon Partnership Facility (FCPF) Readiness Plan Idea Note (R-PIN) Mexico. 2008. Available online: https://www.forestcarbonpartnership.org/sites/ forestcarbonpartnership.org/files/Mexico_FCPF_R-PIN.pdf (accessed on 6 August 2016).

40. Comisión Nacional Forestal (CONAFOR). The Forest Carbon Partnership Facility (FCPF). Readiness Preparation Proposal (R-PP) Mexico. 2010. Available online: http://forestcarbonpartnership.org/sites/fcp/ files/Documents/tagged/Mexico_120211_R-PP_Template_with_disclaimer.pdf (accessed on 6 August 2016).

41. Comisión Nacional Forestal (CONAFOR). Visión de México Sobre REDD+. Hacia una Estrategia Nacional. 2010. Available online: http://www.conafor.gob.mx:8080/documentos/docs/35/2521Visi\%C3\%B3n\% 20de\%20M\%C3\%A9xico\%20para\%20REDD_.pdf (accessed on 6 August 2016). 
42. U'yool'che and Servicios Ecosistémicos de la Selva Maya S.C. Plan Vivo Project Design Document (PDD), Much Kanan K'aax; U'yool'che and Servicios Ecosistémicos de la Selva Maya S.C.: Felipe Carrillo Puerto, Mexico, 2011.

43. Consejo Civil Mexicano para la Silvicultura Sostenible (CCMSS). Nota de Idea del Proyecto REDD+ Comunitario en la Zona Maya de José María Morelos, Quintana Roo. 2011. Available online: http:/ /www.ccmss.org.mx/ descargas/pin_jmm_140711.pdf (accessed on 6 August 2016).

44. PRONATURA. El Zapotal. 2015. Available online: http://www.pronatura-ppy.org.mx/seccion.php?id=5 (accessed on 6 August 2016).

45. Comisión Nacional Forestal (CONAFOR). Estrategia Nacional para REDD+ (ENAREDD+). Primer borrador. 2011. Available online: http://www.conafor.gob.mx:8080/documentos/docs/35/4859Elementos $\%$ 20para $\% 20 \mathrm{el} \% 20 \mathrm{dise} \% \mathrm{C3} \% \mathrm{~B} 1 \mathrm{\%} \% 20 \mathrm{de} \% 201 \mathrm{a} \% 20$ Estrategia\%20Nacional\%20para\%20REDD_.pdf (accessed on 6 August 2016).

46. Comisión Nacional Forestal (CONAFOR). Participación. CTC-REDD+ Estatales. 2015. Available online: http://www.conafor.gob.mx/web/temas-forestales/bycc/redd-en-mexico/participacion/ (accessed on 6 August 2016).

47. Ley General de Desarrollo Forestal Sustentable (LGDFS). El Diario Oficial de la Federación el 25 de Febrero de 2003 (Última Reforma DOF 04-06-2012); Cámara de Diputados del H. Congreso de la Unión, Secretaría General, Secretaría de Servicios Parlamentarios: Mexico city, Mexico, 2016.

48. Ley General del Equilibrio Ecológico y la Protección al Ambiente (LGEEPA). El Diario Oficial de la Federación el 28 de enero de 1988 (Última Reforma DOF 04-06-2012); Cámara de Diputados del H. Congreso de la Unión, Secretaría General, Secretaría de Servicios Parlamentarios: Mexico city, Mexico, 2015.

49. Consejo Nacional Forestal (CONAF). Memoria de Gestión de la Renovación del Consejo Nacional Forestal para el Periodo 2013-2014. Available online: https://www.gob.mx/cms/uploads/attachment/file/82979/ Memoria_de_Gestion_CONAF_2013_-2014.pdf (accessed on 6 August 2016).

50. Jagger, P.; Brockhaus, M.; Duchelle, A.E.; Gebara, M.F.; Lawlor, K.; Resosudarmo, I.A.P.; Sunderlin, W.D. Multi-level policy dialogues, processes, and actions: Challenges and opportunities for national REDD+ safeguards measurement, reporting, and verification (MRV). Forests 2014, 5, 2136-2162. [CrossRef]

51. Comisión Nacional Forestal (CONAFOR). Estrategia Nacional Para REDD+ (ENAREDD+). Borrador Octubre de 2012. Available online: http:/ / www.conafor.gob.mx:8080/documentos/docs/35/5303Elementos\% 20para\%20el\%20dise \%C3\%B1o\%20de\%20la\%20Estrategia\%20Nacional\%20para\%20REDD_.pdf (accessed on 6 August 2016).

52. Comisión Nacional Forestal (CONAFOR). Estrategia Nacional Para REDD+ (ENAREDD+). Borrador Julio de 2013. Available online: http:/ / www.conafor.gob.mx:8080/documentos/docs/35/4861Estrategia\% 20Nacional\%20para\%20REDD_.pdf (accessed on 6 August 2016).

53. Comisión Nacional Forestal (CONAFOR). Estrategia Nacional Para REDD+ (ENAREDD+). Borrador Abril de 2014. Available online: http:/ / www.conafor.gob.mx:8080/documentos/docs/35/5559Elementos\% 20para \%20el\%20dise \%C3\%B1o\%20de\%20la\%20Estrategia\%20Nacional\%20para\%20REDD_.pdf (accessed on 6 August 2016).

54. Comisión Nacional Forestal (CONAFOR). Estrategia Nacional Para REDD+ (ENAREDD+) (Para Consulta Pública). Available online: http://www.conafor.gob.mx:8080/documentos/docs/35/6462Estrategia\%20Nacional\% 20para\%20REDD_\%20(para\%20consulta\%20p\%C3\%BAblica)\%202015.pdf (accessed on 6 August 2016).

55. Comisión Nacional Forestal (CONAFOR). Forest Carbon Partnership Facility (FCPF) Carbon Fund. Emission Reductions Program. Idea Note (ER-PIN) Mexico. Available online: http:/ /www.conafor.gob.mx: 8080/documentos/docs/4/6170Propuesta\%20de\%20Nota\%20de\%20Idea\%20de\%20la\%20Iniciativa\% 20de $\% 20$ Reducci $\%$ C3\%B3n $\% 20 \mathrm{de} \% 20$ Emisiones $\% 20 \% 28$ ERPIN $\% 29 \% 20 \mathrm{de} \% 20 \mathrm{M} \% \mathrm{C} 3 \%$ A9xico.pdf (accessed on 6 August 2016).

56. Forest Carbon Partnership Facility (FCPF). ER-PIN Template. 2013. Available online: http://www. bankinformationcenter.org/wp-content/uploads/2013/12/FCPF-Carbon-Fund-ER-PIN-v4.pdf (accessed on 6 August 2016).

57. Beardsworth, A.; Keil, T. The vegetarian option: Varieties, conversions, motives, and careers. Sociol. Rev. 1992, 40, 253-293. [CrossRef]

58. Bernard, H.R. Research Methods in Anthropology: Qualitative and Quantitative Approaches, 4th ed.; Altamira Press: Walnut Creek, CA, USA, 2006; pp. 186-210. 
59. Angelsen, A.; Bockhaus, M.; Kanninen, M.; Sills, E.; Sunderlin, W.D.; Wertz-Kanounnikoff, S. Realising REDD+: National Strategy and Policy Options; Center for International Forestry Research: Bogor, Indonesia, 2009. Available online: http://www.cifor.org/publications/pdf_files/Books/BAngelsen0902.pdf (accessed on 8 November 2016).

60. Mayers, J. Stakeholder Power Analysis; International Institute for and Environment Development (IIED): London, UK, 2005.

61. Diefenbach, T.; Sillince, J.A.A. Formal and informal hierarchy in different types of organization. Organ. Stud. 2011, 32, 1515-1537. [CrossRef]

62. Overseas Development Administration. Guidance Note on How to Do Stakeholder Analysis of Aid Projects and Programmes; Overseas Development Department: London, UK, 1995.

63. Parkinson, J. Legitimacy problems in deliberative democracy. Polit. Stud. 2003, 51, 180-196. [CrossRef]

64. Hajer, M.A. Discourse coalitions and the institutionalisation of practice: The case of acid rain in Great Britain. In The Argumentative Turn in Policy Analysis and Planning; Fischer, F., Forester, J., Eds.; Duke University Press: Durham/London, UK, 1993; pp. 43-67.

65. Dryzek, J. The Politics of the Earth: Environmental Discourses; Oxford University Press: Oxford, UK, 1997.

66. Adger, W.N.; Benjaminsen, T.A.; Brown, K.; Svarstad, H. Advancing a political ecology of global environmental discourses. Dev. Chang. 2001, 32, 681-715. [CrossRef]

67. Cashore, B. Legitimacy and the privatization of environmental governance: How Non State Market-Driven (NSMD) governance systems gain rule making authority. Governance 2002, 15, 503-529. [CrossRef]

68. Steffek, J. The legitimation of international governance: A discourse approach. Eur. J. Int. Relat. 2003, 9, 249-275. [CrossRef]

69. Steffek, J. Discursive legitimation in environmental governance. For. Policy Econ. 2009, 11, 313-318. [CrossRef]

70. Steffek, J.; Hahn, K. Evaluating Transnational NGOs: Legitimacy, Accountability, Representation; Palgrave Macmillan: Basingstoke, UK, 2011.

71. Buchanan, A.; Keohane, R.O. The legitimacy of global governance institutions. Ethics Int. Aff. 2006, 20, 405-437. [CrossRef]

72. Hajer, M.A. The Politics of Environmental Discourse: Ecological Modernization and the Policy Process; Oxford University Press: New York, NY, USA, 1995; pp. 9-44.

73. Organisation for Economic Co-operation and Development (OECD). Evaluaciones de la OCDE Sobre el Desempeño Ambiental: México 2013; OECD Publishing: Paris, France, 2013.

74. Food and Agriculture Organization of the United Nations (FAO). Evaluación de los Recursos Forestales Mundales, Informe Nacional, México; FAO: Rome, Italy, 2010. Available online: http:/ /www.fao.org/forestry /20262-1176.pdf (accessed on 6 August 2016).

75. De Ita, A. Land concentration in Mexico after PROCEDE. In Promised Land: Competing Visions of Agrarian Reform; Rosset, P.M., Patel, R., Courville, M., Eds.; Institute for Food and Development Policy: Oakland, CA, USA, 2008.

76. Conant, J. A Broken Bridge to the Jungle: The California-Chiapas Climate Agreement Opens Old Wounds; Global Justice Ecology Project. Climate Connections, 7 April 2011. Available online: http://climate-connections.org/ 2011/04/07/a-broken-bridge-to-the-jungle-the-california-chiapas-climate-agreement-opens-old-wounds / (accessed on 31 August 2016).

77. Lang, C. People's Forum Against REDD+ in Chiapas, Mexico. Redd-Monitor, 24 September 2012. Available online: http:/ /www.redd-monitor.org/2012/09/24/peoples-forum-against-redd-in-chiapas-mexico/ (accessed on 21 September 2016).

78. Papel Revolución. Comunicado REDDeldía Leido en el Foro de Gobernadores pro REDD+. Papel Revolución, 27 September 2012. Available online: http://www.papelrevolucion.com/2012/09/comunicado-reddeldialeido-en-el-foro.html (accessed on 21 September 2016).

79. Reddeldia. Open letter from Chiapas about the Agreement between the States of Chiapas (Mexico), Acre (Brazil) and California (USA). Reddeldia, April 2013. Available online: http://reddeldia.blogspot.rs/2013/ 04/carta-abierta-de-chiapas-sobre-el.html (accessed on 21 September 2016).

80. Otros Mundos AC- Friends of the Earth Mexico. REDD: la codicia por los árboles (El Caso Chiapas: la Selva Lacandona al mejor postor). Otros Mundos AC, Friends of the Earth Mexico, 2011. Available online: https:/ / www.youtube.com/watch?v=b0Md6WXj0pM (accessed on 21 September 2016). 
81. Centro de Estudios Para el Cambio en el Campo Mexicano (CECCAM). REDD+ y los territorios indígenas y campesinos; CECCAM: Mexico city, Mexico, 2012. Available online: http://ceccam.org/sites/default/files/ AAA-REDD\%2BWeb.pdf (accessed on 21 September 2016).

82. Phelps, J.; Edward, L.W.; Agrawal, A. Does REDD+ threaten to recentralize forest governance? Policy Forum 2010, 328, 312-313. [CrossRef] [PubMed]

83. Biermann, F.; Betsill, M.M.; Gupta, J.; Kanie, N.; Lebe, L.; Liverman, D.; Schroeder, H.; Siebenhüner, B. Earth System Governance: People, Places and the Planet. Science and Implementation Plan of the Earth System Governance Project; Earth System Governance Report 1, IHDP Report 20; The Earth System Governance Project: Bonn, Germany, 2009.

84. Corbera, E.; Estrada, M.; May, P.; Navarro, G.; Pacheco, P. Rights to land, forests and carbon in REDD+: Insights from Mexico, Brazil and Costa Rica. Forests 2011, 2, 301-342. [CrossRef]

85. Hajjar, R.; Kozlak, A.R.; Inners, J.L. Is decentralization leading to "real" decision-making power for forest dependent communities? Case studies from Mexico and Brazil. Ecol. Soc. 2012, 17, 12. [CrossRef]

86. Yosie, T.; Herbst, T. Using Stakeholder Processes in Environmental Decision Making: An Evaluation of Lessons Learned, Key Issues, and Future Challenges; Ruder Finn Washington: Washington, DC, USA, 1998.

87. Forest Peoples Programme, Civil Society Groups in DRC Suspend Engagement with National REDD Coordination Process. Available online: http:/ /www.forestpeoples.org/topics/redd-and-related-initiatives/ news/2012/07/civil-society-groups-drc-suspend-engagement-nationa (accessed on 6 November 2016).

88. Lang, C. COONAPIP, Panama's Indigenous Peoples Coordinating Body, Withdraws from UN-REDD. REDD-Monitor, 2013. Available online: http:/ /www.redd-monitor.org/2013/03/06/coonapip-panamasindigenous-peoples-coordinating-body-withdraws-from-un-redd/ (accessed on 6 November 2016).

89. Hatanaka, M.; Konefal, F. Legitimacy and standard development in multi-stakeholder initiatives: A case study of the leonardo academy's sustainable agriculture standard initiative. Int. J. Sociol. Agric. Food 2012, 20, 155-173.

90. Boström, M.; Tamm Hallström, K. Global multi-stakeholder standard setters: How fragile are they? J. Glob. Ethics 2013, 9, 93-110. [CrossRef]

91. May, P.H.; Millikan, B.; Gebara, M.F. The Context of REDD+ in Brazil: Drivers, Agents and Institutions; Occasional Paper 55, revised edition; Center for International Forestry Research: Bogor, Indonesia, 2011.

92. Rantala, S.; Di Gregorio, M. Multistakeholder environmental governance in action: REDD+ discourse coalitions in Tanzania. Ecol. Soc. 2014, 19, 66. [CrossRef]

93. Quan, J.; Naess, L.O.; Newsham, A.; Sitoe, A.; Fernandez, M.C. Carbon Forestry and Climate Compatible Development in Mozambique: A Political Economy Analysis; IDS Working Paper No. 448; Institute of Development Studies: Brighton, UK, 2014.

94. Di Gregorio, M.; Brockhaus, M.; Cronin, T.; Muharrom, E.; Santoso, L.; Mardiah, S.; Büdenbender, M. Equity and REDD+ in the Media: A comparative analysis of policy discourses. Ecol. Soc. 2014, 18, 39. [CrossRef]

95. Boedeltje, M.; Cornips, J. Input and Output Legitimacy in Interactive Governance. NIG Annual Work Conference, Rotterdam (No. NIG2-01) 2004. Available online: http:/ /hdl.handle.net/1765/1750 (accessed on 6 August 2016).

96. Hemmati, M. Multi-Stakeholder Processes for Governance and Sustainability beyond Deadlock and Conflict; Earthscan Publications Ltd.: London, UK; Sterling, VA, USA, 2002.

97. Vijge, M.J.; Brockhaus, M.; Di Gregorio, M.; Muharrom, E. Framing REDD+ in the national political arena: A comparative discourse analysis of Cameroon, Indonesia, Nepal, PNG, Vietnam, Peru and Tanzania. Glob. Environ. Chang. 2016, 39, 57-68. [CrossRef]

98. Bushley, R.B. REDD+ policy making in Nepal: Toward state-centric, polycentric, or market-oriented governance? Ecol. Soc. 2014, 19, 34. [CrossRef]

99. Bushley, B.R.; Khatri, D.B. REDD+: Reversing, Reinforcing or Reconfiguring Decentralized Forest Governance in Nepal; Discussion Paper Series 11:3; Forest Action Nepal: Patan, Nepal, 2011.

100. Bastakoti, R.R.; Davidsen, C. Nepal's REDD+ readiness preparation and multi-stakeholder consultation challenges. J. For. Livelihood 2015, 13, 30-43. [CrossRef]

(C) 2016 by the authors; licensee MDPI, Basel, Switzerland. This article is an open access article distributed under the terms and conditions of the Creative Commons Attribution (CC-BY) license (http://creativecommons.org/licenses/by/4.0/). 